\title{
Comparison of subpopulations of luteal cells obtained from cyclic and superovulated ewes*
}

\author{
S. Hild-Petitoł, A. C. Ottobreł and P. B. Hoyer \\ Department of Physiology, University of Arizona, Tucson, AZ 85724, U.S.A.
}

\begin{abstract}
Summary. Peripheral blood samples were collected daily (Days 1-10 after ovulation) and analysed for progesterone content. Luteal tissue was collected on Day 10 after the LH surge, or Day 10 after hCG injection from cyclic and superovulated ewes, respectively. The tissue was enzymically dispersed and an aliquant was utilized for measurement of cell diameters, and staining for $3 \beta$-hydroxy- $\Delta^{5}$-steroid dehydrogenase- $\Delta^{5}, \Delta^{4}$ isomerase activity ( $3 \beta-\mathrm{HSD})$. The remaining cell preparation was separated into small $(10-22 \mu \mathrm{m})$ and large $(>22 \mu \mathrm{m})$ cell fractions by elutriation. Small and large cell suspensions were incubated $\left(37^{\circ} \mathrm{C}, 2 \mathrm{~h}\right)$ in the presence or absence or ovine $\mathrm{LH}(100 \mathrm{ng} / \mathrm{ml})$ or $\operatorname{dbcAMP}(2 \mathrm{mM})$ and progesterone content of the medium was measured. Superovulation did not affect circulating progesterone concentrations, when expressed per mg luteal tissue recorded; basal progesterone production by small or large luteal cells; the unresponsiveness of large luteal cells to ovine LH or dbcAMP; the ratio of small:large cells recovered by dissociation the mean diameter of total cells; or the mean diameter of large cells. However, the mean cell diameter and $\mathrm{LH}$ stimulation of progesterone production by small cells were greater $(P<0.05)$ in luteal tissue collected from superovulated than in that from cyclic ewes. These differences appear to be an amplification of basic function. Therefore, we conclude that corpora lutea obtained from superovulated ewes can be used to study functional aspects of small and large cells.
\end{abstract}

\section{Introduction}

The ovine corpus luteum consists of steroidogenic and non-steroidogenic cell types. Enzymically dispersed luteal cells can be classified as steroidogenic or non-steroidogenic based on the presence of $3 \beta$-hydroxy- $\Delta^{5}$-steroid dehydrogenase- $\Delta^{5}, \Delta^{4}$-isomerase activity ( $3 \beta$-HSD) and the ability to produce progesterone in vitro. Non-steroidogenic cells are typically endothelial cells, blood cells, pericytes and fibroblasts (O'Shea et al., 1979; Rodgers \& O'Shea, 1982). The existence of two distinct steroidogenic cell types has been reported for the corpus luteum of the ewe (O'Shea et al., 1979), the sow (Lemon \& Loir, 1977) and the cow (Chegini et al., 1984; Fields et al., 1985) based on cell size and morphological differences. Studies utilizing enriched fractions of the two cell populations have provided evidence that the two cell types are functionally distinct.

Small luteal cells contain the majority of receptors for luteinizing hormone (LH) and are more responsive to LH than are large cells (Lemon \& Loir, 1977; Ursely \& Leymarie, 1979; Koos \& Hansel, 1981; Fitz et al., 1982; Rodgers \& O'Shea, 1982; Rodgers et al., 1983; Hoyer et al., 1984). Large luteal cells do not possess the ability to respond to $N^{6}-2^{\prime}-0$-dibutyryladenosine $3^{\prime}, 5^{\prime}$ cyclic monophosphate (dbcAMP) with enhanced secretion of progesterone (Fitz et al., 1982; Rodgers $e t$

\footnotetext{
* Reprint requests to Dr P. B. Hoyer.

+Present address: Oregon Regional Primate Research Center, Beaverton, OR 97006, U.S.A.

†Present address: Ohio State University, Department of Dairy Science, Columbus, OH 43210, U.S.A.
} 
al., 1983), although they synthesize cAMP (Hoyer et al., 1984) and possess available intracellular cAMP binding sites on the cAMP-dependent protein kinase (Hoyer \& Niswender, 1985, 1986). On a per cell basis, unstimulated secretion of progesterone by large luteal cells is greater than that by small luteal cells (Lemon \& Loir, 1977; Ursely \& Leymarie, 1979; Koos \& Hansel, 1981; Fitz et al., 1982; Rodgers et al., 1983; Hoyer et al., 1984). These marked differences in regulation between luteal cell types have led to a re-evaluation of traditional concepts of the regulation of luteal function.

Techniques to separate luteal cell types that have been utilized in these studies often require large quantities of tissue since cells are lost throughout the dissociation and separation procedures. Many studies have utilized small and large cells obtained from superovulated ewes (Fitz et al., 1982-1984a, b; Hoyer et al., 1984; Gamboni et al., 1984; Glass et al., 1984; Hoyer \& Niswender, 1985, 1986). However, the effect of superovulation on these subpopulations of cells has not been reported. McClellan et al. (1975) made a direct comparison of the subcellular morphology of the developing $\mathrm{CL}$ induced by superovulation of ewes with that of the normal oestrous cycle. Circulating concentrations of progesterone, up to 4 days after ovulation, were higher in ewes with corpora lutea induced by superovulation. However, by morphological examination of the corpora lutea, the only effect of superovulation reported was that there were more non-steroidogenic cells than in tissue obtained from cyclic ewes. Therefore, the present study was designed to test the effect of superovulation on the size and regulation of steroidogenesis in small and large cell types in the ovine corpus luteum.

\section{Materials and Methods}

Tissue collection. Western range ewes (5-6 years of age) were utilized in this study. For comparison of luteal cell populations from cyclic and superovulated ewes, corpora lutea were obtained during the mid-luteal phase. All data from cyclic ewes were collected during the breeding season (January, February) and superovulation of ewes was begun in February and continued through April. Therefore, values from superovulated ewes were collected during the end of the breeding and beginning of the non-breeding seasons.

Superovulated ewes. Ewes were synchronized with injections of prostaglandin (PG) F-2 $\alpha$ (Lutalyse; Upjohn Company, Kalamazoo, MI, U.S.A.; $10 \mathrm{mg}$ i.m.) on Days -12 and -3 . Follicular development was induced with a subcutaneous injection of PMSG (supplied by Dr H. Papkoff; 1000 i.u.; Day -3) followed on Day 0 with an injection of hCG (Sigma Chemical Co., St Louis, MO, U.S.A.; 750 i.u., i.v.; Gamboni et al., 1984).

Cyclic ewes. Daily blood samples were collected from cyclic ewes for two successive oestrous cycles. The serum was analysed for progesterone content by radioimmunoassay (RIA) and the LH surge was estimated from the pattern of circulating progesterone concentrations for these two cycles (Thorburn et al., 1969). Briefly, the following criteria were considered for assigning Day 0 (LH surge): Day 0-3, circulating progesterone concentrations $<0.4 \mathrm{ng} / \mathrm{ml}$; Day 14 or 15 , rapid decline in progesterone values (falling below $1 \mathrm{ng} / \mathrm{ml}$ ); Day 0, non-detectable progesterone values.

A cycle length was estimated for each ewe (found to be 16 or 17 days in every case) and a day of ovulation was projected for each of the next 3 cycles. Serum samples were collected beginning 3 days before the estimated day of ovulation and until collection of the corpus luteum. By this method, subsequent measurement of circulating concentrations of progesterone provided evidence that the tissue collected had been obtained in the mid-luteal phase (about Day 10).

Corpora lutea were surgically collected on Day 10 after the estimated LH surge or hCG injection from cyclic and superovulated ewes, respectively. Pentobarbitone sodium $(1000-1100 \mathrm{mg} / \mathrm{ewe})$ was used for anaesthesia. Surgical collection was by mid-ventral laparotomy with CL excision for cyclic ewes and ovariectomy of superovulated ewes. Some of the cyclic ewes were later utilized for superovulation induction. Cyclic ewes provided 1 or $2 \mathrm{CL}$ with a mean weight of $0.66 \pm 0.07 \mathrm{~g} / \mathrm{CL}$. Superovulated ewes gave $1-5 \mathrm{CL}$ with a mean weight of $0.82 \pm 0.15 \mathrm{~g} / \mathrm{CL}$. Mean luteal weights were not different $(P>0.05)$ between cyclic and superovulated ewes. Corpora lutea from each ewe were pooled for dissociation and elutriation.

Tissue preparation. Surgically collected corpora lutea were decapsulated and enzymically dissociated into singlecell suspensions $(0.4 \%$ collagenase: Worthington Biochemical, Malvern, PA, U.S.A.; $0.005 \%$ DNAse: Sigma; complete Hank's, solution; pH 7.35) according to the method of Ahmed et al. (1981). The distribution of cell populations was determined by measuring 300 steroidogenic cells per observation on an inverted microscope (Nikon) equipped with an ocular micrometer calibrated for 300 -fold magnification ( 1 division $=1 \cdot 7 \mu \mathrm{m}$ ). Cell counts were done with a haemocytometer; diameter measurements (wet mounts) were made on glass slides. Small luteal cells were designated as steroidogenic cells with a diameter of $12-22 \mu \mathrm{m}$, and large cells as those with a diameter of $>22 \mu \mathrm{m}$ (Fitz et al., 1982). Using these criteria, a small to large cell ratio, and mean cell diameters for total steroidogenic cells, small cells and large cells were calculated. 
Single-cell suspensions were separated into small and large cell fractions by elutriation as described by Fitz et al. (1982). The large cell fraction was typically contaminated with $30-45 \%$ small steroidogenic cells, whereas the small cell fraction was free of large cells $(>22 \mu \mathrm{m})$. Cell viability was estimated microscopically by Trypan blue dye exclusion. Before elutriation, cell viabilities were typically $99 \%$ and viabilities of elutriated cells in the small and large fractions were greater than $95 \%$.

Aliquants of mixed cell suspensions and aliquants of small and large cell fractions were fixed in $1 \%$ paraformaldehyde $\left(20 \mathrm{~min}\right.$ at $\left.4^{\circ} \mathrm{C}\right)$. The fixed cells were rinsed $(0.1 \mathrm{M}$-phosphate buffer, $\mathrm{pH} 7 \cdot 4)$, applied to slides coated with $1 \%$ gelatin, allowed to air dry, and stained in Coplin jars for the presence of $3 \beta$-HSD (steroidogenic) enzyme activity $\left(37^{\circ} \mathrm{C}, 1.5 \mathrm{~h}\right.$ : Payne et al., 1980).

Cell incubations. Suspensions of small $\left(3.5-5 \times 10^{4} / \mathrm{ml}\right)$ or large $\left(1-3.5 \times 10^{4} / \mathrm{ml}\right)$ luteal cells were incubated in $12 \times 75 \mathrm{~mm}$ disposable culture tubes containing Medium 199 (M199; Gibco Co., Grand Island, NY, U.S.A.). Cell suspensions were incubated in the absence or presence of ovine $\mathrm{LH}(100 \mathrm{ng} / \mathrm{ml}$; a concentration known to stimulate progesterone production maximally in small cells: Bourdage et al., 1984) or with dbcAMP (2 mM; Sigma). Incubations were carried out in a New Brunswick metabolic shaker at $37^{\circ} \mathrm{C}$ for $2 \mathrm{~h}$. At the end of the incubation period, the medium was collected after centrifugation of the cells $\left(900 \mathrm{~g}, 22^{\circ} \mathrm{C}\right)$. The concentration of progesterone in the medium was determined by RIA. Progesterone content of the medium from large luteal cell incubations was corrected for the contribution made by small luteal cells. This correction was done by expressing the values obtained after incubation of pure small cells during each experiment on a per cell basis and then correcting for the number of small cells present in the preparation of large cells for each datum point (Hoyer et al., 1984).

Progesterone assay. Concentrations of progesterone in serum and culture medium were measured by radioimmunoassay as described by Cameron \& Stouffer (1982) and Stouffer et al. (1976), respectively, with some modifications. Progesterone was extracted from $50 \mu \mathrm{l}$ serum using $4 \mathrm{ml}$ petroleum ether after dilution with $0 \cdot 3 \mathrm{ml}$ saline. Extraction recovery was estimated in each assay by adding $100 \mathrm{pg}$ progesterone (Radioassay Systems Laboratories, Inc., Orinda, CA, U.S.A.) to $50 \mu \mathrm{l}$ of pooled sheep serum and determining by radioimmunoassay the amount of added hormone recorded. Extraction recoveries were typically $>95 \%$ and samples were corrected for recovery within each assay. Unextracted medium was assayed for progesterone using $100 \mu 1 /$ assay tube. Samples were diluted with Medium 199 and dilutions ranged from $I: 1$ to $1: 100$.

The antiserum, GDN-337, was used at a 1:5000 dilution. Assay sensitivity was defined as the content of progesterone which corresponded to the counts per minute that were 2 standard deviations below the mean of the 0 pg value. The percentage binding at sensitivity was $90 \%$ (s.e. 1.21 ) for 10 assays and reflected a tube content of $3.0 \mathrm{pg}$. The coefficients of variation were $4.24 \%$ between assays and $4.56 \%$ within assays.

Repeatability of estimates of concentrations of progesterone between volumes of sample was determined by assaying a pool of sheep serum at four different volumes $(25,50,100$ and $250 \mu \mathrm{l})$, and a medium pool with progesterone added at $5 \mathrm{ng} / \mathrm{ml}$ at 5 volumes $(4,10,25,50$ and $100 \mu \mathrm{l})$. The intraclass correlations of concentrations among volumes were 0.999 for serum and 0.997 for medium. The repeatability of estimates of concentration of progesterone between a previously validated assay (Cameron \& Stouffer, 1982) and the radioimmunoassay using GDN-337 was assessed by quantifying the progesterone in several serum and medium samples by both assays. The intraclass correlation of concentrations between assays was 0.96 for serum and 0.95 for medium.

Statistical analyses. Differences between mean cell diameters and small:large cell ratios were compared by Student's $t$ test. Differences between progesterone content from small and large cell incubations were compared by analysis of variance followed by a Student-Newman-Keuls multiple range test.

\section{Results}

Serum progesterone concentrations were determined daily for cyclic and superovulated ewes. The results were normalized to the estimated day of LH surge (Day 0 ) for cyclic ewes or to the day of hCG injection (Day 0 ) for superovulated ewes. Circulating concentrations of progesterone (ng/ml) were higher $(P<0.05)$ in superovulated $(2 \cdot 1 \pm 0 \cdot 3$, Day $8 ; 2.6 \pm 0 \cdot 1$, Day 10$)$ than in cyclic $(1 \cdot 4 \pm 0 \cdot 3$, Day $8 ; 1 \cdot 8 \pm 0 \cdot 2$, Day 10$)$ ewes. However, superovulation had no effect $(P>0.05)$ on circulating progesterone values when expressed as a function of luteal tissue weight (Fig. 1).

Mean diameters of total steroidogenic and large cells $(>22 \mu \mathrm{m})$ and small:large cell ratio did not differ $(P>0.05)$ between suspensions of steroidogenic cells obtained from cyclic and superovulated ewes. However, the mean diameter of small cells was greater $(P<0.05)$ in superovulated ewes than in cyclic ewes (Table 1). Therefore, superovulation had no appreciable effect on size distribution of steroidogenic cells recovered except for an increase in mean cell diameter of small luteal cells (Fig. 2).

Dispersed luteal cell suspensions obtained from cyclic or superovulated ewes (Day 10), contained small and large steroidogenic cells (those staining positive for $3 \beta$-HSD-activity) and nonsteroidogenic small cells (Fig. 3a, b). However, mixed cell suspensions from superovulated ewes 


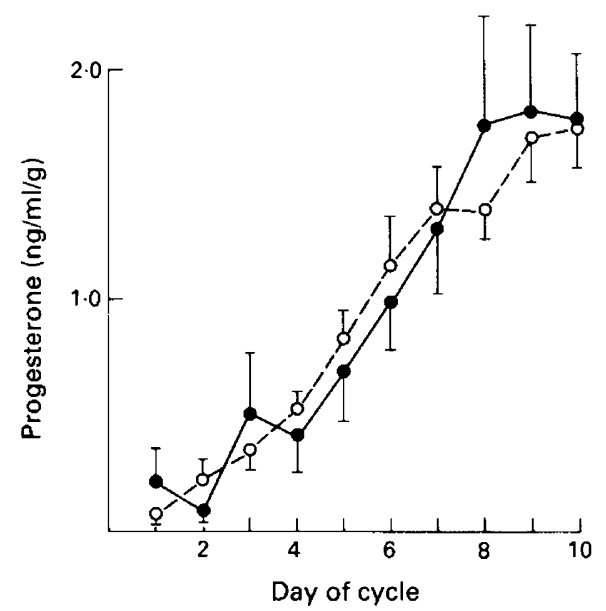

Fig. 1. Circulating concentrations of progesterone in cyclic $(O--O, N=6)$ and superovulated $(--O, N=5)$ ewes on Days 1-10 of the luteal phase. Values are the mean \pm s.e.m. and represent $\mathrm{ng} / \mathrm{ml}$ progesterone estimated for each day of the cycle based on grams of luteal tissue recovered on D10. Days are normalized to the LH surge or hCG injection for cycling and superovulated ewes, respectively, as described in 'Materials and Methods'.

Table 1. A comparison of the size distribution of cells recovered from corpora lutea of cyclic and superovulated ewes

\begin{tabular}{lcccc}
\hline & & \multicolumn{3}{c}{ Mean cell diameter $(\mu \mathrm{m})$} \\
\cline { 3 - 5 } & $\begin{array}{c}\text { Small:large } \\
\text { cell ratio }\end{array}$ & $\begin{array}{c}\text { Total } \\
\text { steroidogenic } \\
\text { cells }\end{array}$ & $\begin{array}{c}\text { Small } \\
\text { cells }\end{array}$ & $\begin{array}{c}\text { Large } \\
\text { cells }\end{array}$ \\
\hline $\begin{array}{c}\text { Cyclic ewes } \\
(\mathrm{N}=6)\end{array}$ & $2.6 \pm 0.6$ & $20 \cdot 0 \pm 1.0$ & $15.0 \pm 0.4^{*}$ & $30.0 \pm 1 \cdot 1$ \\
$\begin{array}{c}\text { Superovulated ewes } \\
(\mathrm{N}=5)\end{array}$ & $4.0 \pm 1.6$ & $20.0 \pm 1.4$ & $17.0 \pm 0.4^{*}$ & $29.0 \pm 0.3$ \\
\hline
\end{tabular}

Values represent mean \pm s.e.m.

${ }^{*} P<0.05$.

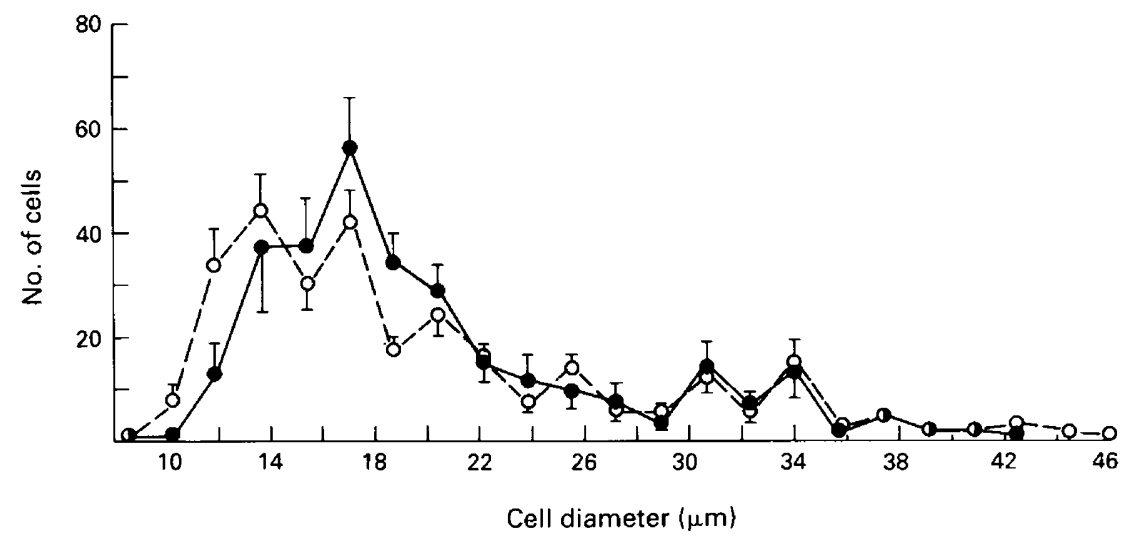

Fig. 2. Size distribution of dispersed luteal cells recovered from corpora lutea collected on Day 10 of the cycle (luteal phase) in cyclic $(O--O, N=6)$ or superovulated $(0--0, N=5)$ ewes. Values represent the mean \pm s.e.m. number of cells of each size in 300 cells measured per observation. 

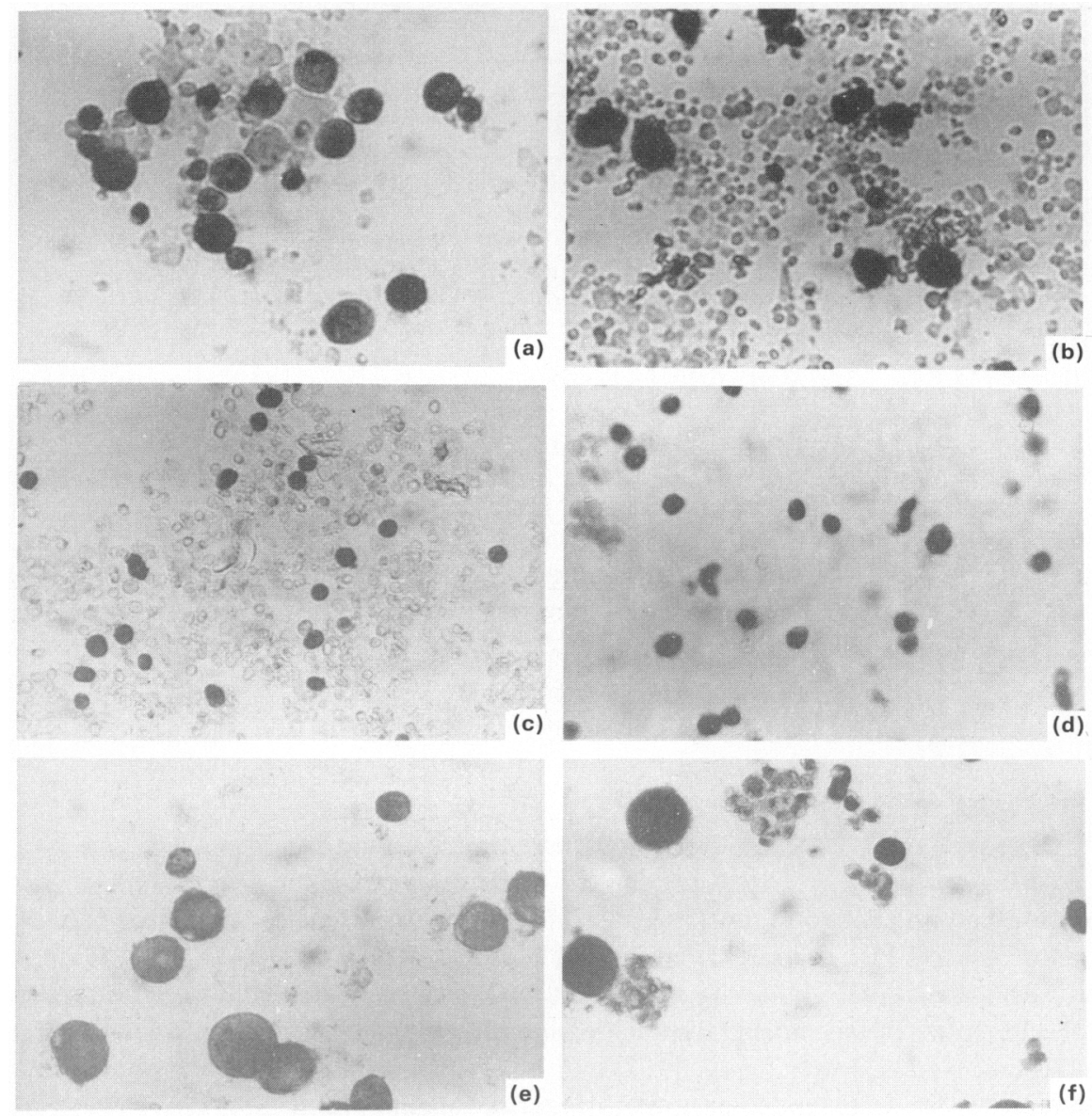

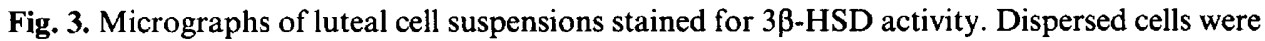
prepared from corpora lutea obtained on Day 10 of the luteal phase in cyclic $(a, c, e)$ or superovulated $(b, d, f)$ ewes and stained for $3 \beta$-HSD activity (positively staining cells appear black). After dissociation, mixed cell suspensions $(a, b)$ were separated into small $(c, d)$ and large $(e, f)$ cell fractions by elutriation. $\times 300$.

contained more non-steroidogenic cells (Fig. 3b) than did those from cyclic ewes (Fig. 3a). This is in agreement with a similar observation reported by McClellan et al. (1975). Elutriation of the cell suspensions provided a pure fraction of small steroidogenic cells $(<22 \mu \mathrm{m}$; Fig. 3c, d) and an enriched population of large cells ( $>22 \mu \mathrm{m}$, Fig. 3e, f).

Progesterone production in incubations of small and large luteal cells is summarized in Table 2. On a per cell basis, unstimulated secretion of progesterone by large luteal cells was greater $(P<0.01)$ than unstimulated secretion by small luteal cells.

Small luteal cells obtained from superovulated ewes responded to LH and dbcAMP with an increase in progesterone production $(P<0.01$ and $P<0.05$, respectively). Progesterone production by small luteal cells obtained from cyclic ewes was enhanced by LH although this increase was not significant $(P>0.05)$. The stimulation above basal with LH and dbcAMP was significantly higher $(P<0.01$ and $P<0.05$, respectively) in small cells obtained from superovulated ewes than those from cyclic ewes $(5.3 \pm 1.0 v s 2.5 \pm 0 \cdot 4$-fold increase for $\mathrm{LH}$ and $4.1 \pm 0 \cdot 7 v s 1.7 \pm 0 \cdot 3$-fold increase for dbcAMP). Secretion of progesterone by large luteal cell fractions from cyclic or superovulated ewes was not stimulated by LH or dbcAMP $(P>0.05)$. 
Table 2. Secretion of progesterone by suspended small and large luteal cells incubated $\left(2 \mathrm{~h}, 37^{\circ} \mathrm{C}\right)$ in Medium 199 without or with ovine $\mathrm{LH}(100 \mathrm{ng} / \mathrm{ml})$ or dbcAMP (2 mM)

\begin{tabular}{|c|c|c|}
\hline & \multicolumn{2}{|c|}{ Progesterone (ng/ $10^{5}$ cells) } \\
\hline & $\begin{array}{l}\text { Cyclic ewes } \\
(\mathrm{N}=6)\end{array}$ & $\begin{array}{c}\text { Superovulated } \\
\text { ewes } \\
(N=5)\end{array}$ \\
\hline \multicolumn{3}{|l|}{ Small cells } \\
\hline Basal & $2 \cdot 62 \pm 0.41$ & $2.02 \pm 0.61$ \\
\hline LH & $6.35 \pm 1.91$ & $9 \cdot 72 \pm 2 \cdot 14^{* *}$ \\
\hline dbcAMP & $3.46 \pm 0.92$ & $7 \cdot 34 \pm 1 \cdot 35^{*}$ \\
\hline \multicolumn{3}{|l|}{ Large cells } \\
\hline Basal & $65.89 \pm 24.20$ & $94.54 \pm 19 \cdot 28$ \\
\hline LH & $118.80 \pm 39.50$ & $220 \cdot 32 \pm 70 \cdot 56$ \\
\hline dbcAMP & $111.60 \pm 38.96$ & $190.37 \pm 56.36$ \\
\hline
\end{tabular}

\section{Discussion}

Superovulation had no effect on the values measured except for an increase in size (Table 1, Fig. 2) and responsiveness to LH and dbcAMP in the small luteal cell population (Table 2). Gamboni et al. (1984) and Farin et al. (1985) have suggested that LH/hCG promotes differentiation of small into large luteal cells. It has been reported that hCG has a long circulating half life when compared with LH (Wehmann \& Nisula, 1981; Tyrey, 1982) and hCG has been demonstrated to interact with its membrane receptor for an extended period of time (Niswender et al., 1985). Therefore, the increase in diameter of small cells from superovulated ewes may be due to a prolonged effect of hCG.

Previous studies on luteal cell populations obtained from cyclic ewes (Rodgers \& O'Shea, 1982; Rodgers et al., 1983, 1985) have shown that small luteal cells in vitro are quite responsive to LH (3-4-fold stimulation of secretion of progesterone). Further, LH stimulation $(P<0.05)$ of secretion of progesterone in small cells from superovulated ewes ranged from 3- to 13-fold (Fitz et al., 1982; Hoyer et al., 1984; Hoyer \& Niswender, 1985). In the present study, an LH enhancement of progesterone production by small luteal cells from cyclic ewes $(2.5 \pm 0 \cdot 4$-fold $)$ was not significant $(P>0.05)$, while that from superovulated ewes $(5 \cdot 3 \pm 1 \cdot 0$-fold $)$ was $(P<0.01)$.

The increased responsiveness to $\mathrm{LH}$ in small cells from superovulated as compared with cyclic ewes may be due to one of several reasons. The previous studies reported above used different criteria of separation between small and large cell fractions. A diameter of $19.4 \mu \mathrm{m}$ separated small and large cell fractions prepared from cyclic ewes by Ficoll gradient centrifugation (Rodgers \& O'Shea, 1982), whereas those fractions prepared by elutriation from superovulated ewes (Fitz et al., 1982; Hoyer et al., 1984; Hoyer \& Niswender, 1985, 1986; the present study) were separated at a diameter of $22 \mu \mathrm{m}$. Since small cells from cyclic ewes are smaller $(P<0.05)$ than those from superovulated ewes (Table 1), it is possible that small cell fractions from cyclic ewes in the current experiments contained cells $(19 \cdot 4-22 \mu \mathrm{m})$ that functionally behaved as large cells. If so, this would result in decreased stimulation of secretion of progesterone by LH in the small cell fraction from cyclic as compared to superovulated ewes. Morphometric studies would further resolve this issue.

Alternatively, an enhanced responsiveness to LH of small cells in superovulated ewes may result from increased luteal receptors caused by supra-physiological levels of gonadotrophin. FSH 
increases the number of LH receptors before ovulation (Erickson et al., 1979; May et al., 1980) and LH can increase the number of its own receptors (Hsueh et al., 1977; Huhtaniemi et al., 1978; Suter et al., 1980). However, the enhancement of steroidogenic response in small cells could not be limited solely to an increase in receptors for $\mathrm{LH}$, since the same enhancement was seen in the presence of dbcAMP (Table 2), an agent whose stimulatory effect bypasses the receptor. Therefore, an effect of superovulation on LH-regulated steroidogenesis of small cells may be that of enhancing the generalized steroidogenic response.

The large luteal cell population did not respond $(P>0.05)$ to LH or dbcAMP when obtained from cyclic ewes, and superovulation did not affect this lack of a response (Table 2). Furthermore, superovulation did not affect the ability of large cells to produce higher $(P<0.01)$ basal levels of progesterone than small luteal cells, on a per cell basis (Table 2). This is in agreement with previous experiments performed on cyclic (Rodgers \& O'Shea, 1982; Rodgers et al., 1983) and superovulated (Fitz et al., 1982; Hoyer et al., 1984) ewes.

These observations suggest that small and large cell populations recovered from the sheep corpus luteum after superovulation are functionally comparable to those of the oestrous cycle. Superovulation increases the amount of non-steroidogenic tissue (McClellan et al., 1975; Fig. 3) as well as the size of small cells and their responsiveness to ovine LH (Tables 1 and 2). This effect on small but not large luteal cells appears to be an amplification of functional differences between small and large cells. While there may be effects of superovulation on aspects of luteal function not measured in this study, we conclude that the superovulated ewe provides a model that is qualitatively similar to the cyclic ewe for studying differences in the regulation of steroidogenesis with respect to distinct luteal cell types.

We thank Dr G. D. Niswender for the antibody to progesterone (GDN 337) and Dr H. Papkoff for the PMSG. This research was supported in part by NIH grants HL07249 and RR05675.

\section{References}

Ahmed, C.E., Sawyer, H.R. \& Niswender, G.D. (1981) Internalization and degradation of human chorionic gonadotropin in ovine luteal cells: kinetic studies. Endocrinology 109, 1380-1387.

Bourdage, R.J., Fitz, T.A. \& Niswender, G.D. (1984) Differential steroidogenic responses of ovine luteal cells to ovine luteinizing hormone and human chorionic gonadotropin. Proc. Soc. exp. Biol. Med. 176, 483-486.

Cameron, J.L. \& Stouffer, R.L. (1982) Gonadotropin receptors of the primate corpus luteum. II. Changes in available luteinizing hormone- and chorionic gonadotropin-binding sites in macaque luteal membranes during the nonfertile menstrual cycle. Endocrinology 110, 2068-2073.

Chegini, N., Ramani, N. \& Rao, C.V. (1984) Morphological and biochemical characterization of small and large bovine luteal cells during pregnancy. Molec. cell. Endocr. 37, 89-102.

Erickson, G.F., Wang, C. \& Hsueh, A.J.W. (1979) FSH induction of functional $\mathrm{LH}$ receptors in granulosa cells cultured in a chemically defined medium. Nature, Lond. 279, 336-338.

Farin, C.E., Schwall, R.H., Gamboni, F., Sawyer, H.R. \& Niswender, G.D. (1985) Effect of LH and hCG on size distributions of luteal cells in the cycling ewe. Biol. Reprod. 32 (Suppl. 1), Abstr. 13.

Fields, M.J., Dubois, W. \& Fields, P.A. (1985) Dynamic features of luteal secretory granules: ultrastructural changes during the course of pregnancy in the cow. Endocrinology 117, 1675-1682.

Fitz, T.A., Mayan, M.H., Sawyer, H.R. \& Niswender, G.D. (1982) Characterization of two steroidogenic cell types in the ovine corpus luteum. Biol. Reprod. 17, 703-711.

Fitz, T.A., Hoyer, P.B. \& Niswender, G.D. (1984a) Interactions of prostaglandins with subpopulations of ovine luteal cells. I. Stimulatory effects of prostaglandins $\mathrm{E}_{1}, \mathrm{E}_{2}$, and $\mathrm{I}_{2}$. Prostaglandins 28, 119-126.

Fitz, T.A., Mock, E.J., Mayan, M.H. \& Niswender, G.D. (1984b) Interactions of prostaglandins with subpopulations of ovine luteal cells. II. Inhibitory effects of $\mathrm{PGF}_{2 a}$ and protection by $\mathrm{PGE}_{2}$. Prostaglandins 28, 127-135.

Gamboni, F., Fitz, T.A., Hoyer, P.B., Wise, M.E., Mayan, M.H. \& Niswender, G.D. (1984) Effect of $\mathrm{hCG}$ on induced ovine corpora lutea during the anestrous season. Domestic Anim. Endocr. 1, 79-88.

Glass, J.D., Fitz, T.A. \& Niswender, G.D. (1984) Cytosolic receptor for estradiol in the corpus luteum of the ewe: variation throughout the estrous cycle and distribution between large and small steroidogenic cell types. Biol. Reprod. 31, 967-974.

Hoyer, P.B. \& Niswender, G.D. (1985) The regulation of steroidogenesis is different in the two types of ovine luteal cells. Can. J. Physiol. Pharm. 63, 240-248. 
Hoyer, P.B. \& Niswender, G.D. (1986) Adenosine 3',5'monophosphate-binding capacity in small and large ovine luteal cells. Endocrinology 119, 1822-1829.

Hoyer, P.B., Fitz, T.A. \& Niswender, G.D. (1984) Hormone-independent activation of adenylate cyclase in large steroidogenic ovine luteal cells does not result in increased progesterone secretion. Endocrinology 114, 604-608.

Hsueh, A.J., Dufau, M.L. \& Catt, K.J. (1977) Gonadotropin-induced regulation of luteinizing hormone receptors and desensitization of testicular $3^{\prime}: 5^{\prime}$-cyclic AMP and testosterone response. Proc. natn. Acad. Sci. U.S.A. 74, 592-595.

Huhtaniemi, I., Martikainen, H. \& Tikkala, L. (1978) hCG-induced changes in the number of rat testis LH/CG receptor. Molec. cell. Endocr. 11, 43--50.

Koos, R.D. \& Hansel, W. (1981) The large and small ceils of the bovine corpus luteum: ultrastructural and functional differences. In Dynamics of Ovarian Function, pp. 197-202. Eds N. B. Schwartz \& M. Hunzicker-Dunn. Raven Press, New York.

Lemon, M. \& Loir, M. (1977) Steroid release in vitro by two luteal cell types in the corpus luteum of the pregnant sow. J. Endocr. 72, 351-359.

May, J.V., McCarty, K., Reichert, L.E. \& Schomberg, D.W. (1980) FSH-mediated induction of functional LH-hCG receptors during monolayer culture of porcine granulosa cells. Endocrinology 107, 10411049.

McClellan, M.C., Diekman, M.A., Abel, J.H. \& Niswender, G.D. (1975) Luteinizing hormone, progesterone and the morphological development of normal and superovulated corpora lutea in sheep. Cell Tiss. Res. 164, 291-307.

Niswender, G.D., Roess, D.A., Sawyer, H.R., Silvia, W.J. \& Barisas, B.G. (1985) Differences in the lateral mobility of receptors for luteinizing hormone (LH) in the luteal cell plasma membrane when occupied by ovine LH versus human chorionic gonadotropin. Endocrinology 116, 164-169.

O'Shea, J.D., Cran, D.G. \& Hay, M.F. (1979) The small luteal cell of the sheep. J. Anat. 128, 239-251.
Payne, A.H., Downing, J.R. \& Wong, K-L. (1980) Luteinizing hormone receptors and testosterone synthesis in two distinct populations of Leydig cells. Endocrinology 106, 1424-1429.

Rodgers, R.J. \& O'Shea, J.D. (1982) Purification, morphology and progesterone production and content of three cell types isolated from the corpus luteum of the sheep. Austr. J. biol. Sci. 35, $441-445$.

Rodgers, R.J., O'Shea, J.D. \& Findlay, J.K. (1983) Progesterone production in vitro by small and large ovine luteal cells. J. Reprod. Fert. 69, 113-124.

Rodgers, R.J., O'Shea, J.D. \& Findlay, J.K. (1985) Do small and large luteal cells of the sheep interact in the production of progesterone? J. Reprod. Fert. 75, 85-94.

Stouffer, R.L., Nixon, W.E., Gulyas, B.J., Johnson, D.K. \& Hodgen, G.D. (1976) In vitro evaluation of corpus luteum function of cycling and pregnant rhesus monkeys: progesterone production by dispersed luteal cells. Steroids 27, 543-551.

Suter, D.E., Fletcher, P.W., Sluss, P.M., Reichert, L.E. \& Niswender, G.D. (1980) Alterations in the number of ovine luteal receptors for $\mathrm{LH}$ and progesterone secretion induced by homologous hormone. Biol. Reprod. 23, 205-210.

Thorburn, G.D., Bassett, J.M. \& Smith, I.D. (1969) Progesterone concentration in the peripheral plasma of sheep during the oestrous cycle. J. Endocr. 45, $459-469$.

Tyrey, L. (1982) Human chorionic gonadotropin: structural, biologic, and immunologic aspects. Seminars in Oncology 9, 163-173.

Ursely, J. \& Leymarie, P. (1979) Varying response to LH of two luteal cell types isolated from bovine corpus luteum. J. Endocr. 83, 303-310.

Wehmann, R.E. \& Nisula, B.C. (1981) Metabolic and renal clearance rates of purified human chorionic gonadotropin. J. clin. Invest. 68, 184-194.

Received 4 November 1986 